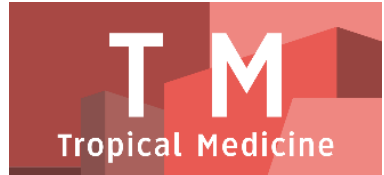

PAPER - OPEN ACCESS

\title{
Aktivitas Antiradikal Berbagai Fraksi dari Ekstrak Etanol dan Ekstrak Etil Asetat Daun Eugenia uniflora L
}

\author{
Author $\quad$ : Wahyu Utami \\ DOI $\quad: 10.32734 /$ tm.v1i3.277 \\ Electronic ISSN $\quad: 2623-0542$ \\ Print ISSN : :2623-0550
}

Volume 1 Issue 3 - 2018 TALENTA Conference Series: Tropical Medicine (TM)

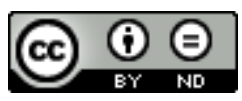

This work is licensed under a Creative Commons Attribution-NoDerivatives 4.0 International License.

Published under licence by TALENTA Publisher, Universitas Sumatera Utara
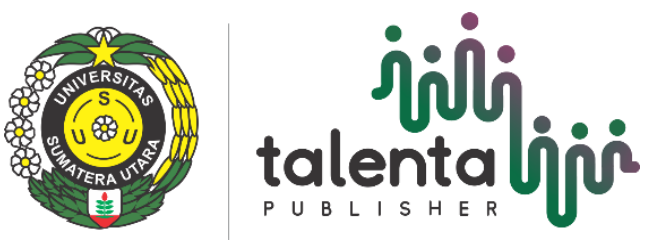


\title{
Aktivitas Antiradikal Berbagai Fraksi dari Ekstrak Etanol dan Ekstrak Etil Asetat Daun Eugenia uniflora L.
}

\author{
Wahyu Utami**, Muhammad Da'i, Viesa Rahayu, Prihantini Kurnia Sari, \\ Dian Werdhi Kusumanegara, Anik Rohayati \\ ${ }^{a}$ Fakultas Farmasi, Universitas Muhammadiyah Surakarta
}

wahyu.utami@ums.ac.id

\begin{abstract}
Abstrak
Penelitian pendahuluan tentang aktivitas antioksidan ekstrak etanol dan ekstrak etil asetat daun dewandaru (Eugenia uniflora L.) menunjukkan potensi anti radikal bebas yang tinggi dari kedua ekstrak. Oleh karena itu telah dilakukan fraksinasi ekstrak etanol dan ekstrak etil asetat daun dewandaru, serta pengujian aktivitas antiradikal dari masing-masing fraksi. Selain itu, penelitian ini juga bertujuan untuk mengetahui apakah ada korelasi antara kandungan fenol dan flavonoid total dalam berbagai fraksi tersebut dengan aktivitas antiradikalnya. Daun dewandaru diekstraksi dengan kloroform, etil asetat, dan etanol secara maserasi bertingkat. Selanjutnya dilakukan fraksinasi terhadap masing-masing ekstrak etanol dan ekstrak etil asetat menggunakan kromatografi kolom gravitasi dengan fase diam silika $\mathrm{G}_{60}$ dan fase gerak campuran perbandingan tertentu antara kloroform, etil asetat, etanol, dan air secara gradien kepolaran. Aktivitas antiradikal diukur secara spektrofotometri dengan pereaksi DPPH (2,2-diphenyl-1-picrylhidrazyl) dan sebagai pembanding digunakan vitamin E. Penentuan kadar fenol dan flavonoid total dalam fraksi secara spektrofotometri menggunakan pereaksi Folin Ciocalteu untuk penetapan kadar fenol total, sedangkan untuk penentuan kadar flavonoid total menggunakan pereaksi $\mathrm{AlCl}_{3}$. Hasil penelitian menunjukkan bahwa fraksi-fraksi dari ekstrak etil asetat dan ekstrak etanol daun dewandaru mempunyai aktivitas antiradikal yang cukup tinggi. Lima fraksi dari ekstrak etanol memiliki aktivitas antiradikal lebih tinggi dibanding vitamin E. Aktivitas antiradikal paling tinggi ditunjukkan dengan nilai ARP (antiradical power) sebesar 3496,5 mg DPPH/mg sampel, sedangkan vitamin E sebesar 1776,20 mg DPPH/mg sampel. Korelasi antara kadar fenol maupun flavonoid total dalam berbagai fraksi tersebut dengan aktivitas antiradikalnya menunjukkan korelasi positif dengan korelasi sebesar 0,55 dan 0,45. Berdasarkan hasil diatas dapat disimpulkan bahwa fraksi-fraksi polar daun dewandaru mempunyai aktivitas antiradikal yang lebih tinggi daripada vitamin E, namun aktivitas tersebut berkorelasi rendah dengan kandungan fenol dan flavonoid totalnya.
\end{abstract}

Kata kunci: antiradikal, fenol, flavonoid, dewandaru, Eugenia uniflora L.

\begin{abstract}
Earlier experiment on the extracts of leaves from dewandaru (Eugenia uniflora L.) showed that those extracts have high potency as antiradical agent. Therefore, this experiment has been done to investigate further the antiradical activity of the fractions of the ethanolic and ethyl acetate leaf extract of E. uniflora; also to study the relationship between the phenol and flavonoid contents of those fractions and the antiradical activity. The leaves of E. uniflora were extracted by using chloroform, ethyl acetate and ethanol by gradient maceration method. Those extracts were fractionated with column chromatography by using silica $\mathrm{G}_{60}$ as solid phase and the composition of chloroform, ethyl acetate, ethanol and water as mobile phase. The antiradical activity was measured by spectrometry method using DPPH (2,2-diphenyl-1-picrylhidrazy) method compared to vitamin $\mathrm{E}$. The phenol and flavonoid content were measured spectrometrically using Folin ciocalteu and $\mathrm{AlCl}_{3}$ reagent. The result has shown that the fractions of the ethyl acetate and ethanol extract had high antiradical activity. Five fractions of ethanol extract had higher antiradical activity than vitamin E. The ARP (antiradical power) value of fraction whose the highest activity is $3496.5 \mathrm{mg} \mathrm{DPPH} / \mathrm{mg}$ sample, which vitamin E is about $1776.2 \mathrm{mg}$ DPPH/mg sample. Moreover, the correlation between the phenol and flavonoid content of the fractions and the antiradical activity are 0.55 and 0.45 . This study has found that the polar fractions of leaves of $E$. uniflora have the higher antiradical activity than vitamin E. However, there is a low relationship between the phenol and flavonoid content of the fractions and the antiradical activity.
\end{abstract}

Keywords: antiradical, phenol, flavonoid, dewandaru, Eugenia uniflora, L.

\section{Pendahuluan}

Antioksidan diperlukan salah satunya untuk melindungi tubuh dari kerusakan akibat stres oksidatif yang dipicu karena serangan radikal bebas [1]. Stres oksidatif berimplikasi pada inisiasi dan progresi berbagai penyakit neurodegenerative, kanker, penyakit jantung, dan penuaan dini [2]. Antioksidan sintetik seperti BHA (butil hidroksi anisol) dan BHT (butil hidroksi toluen) memiliki aktivitas antioksidan yang lebih tinggi dibanding antioksidan alami seperti vitamin $\mathrm{C}$ dan vitamin $\mathrm{E}$ [3], tetapi 
antioksidan sintetik memiliki kelemahan dapat menimbulkan karsinogenesis [4]. Eksplorasi senyawa antioksidan diharapkan dapat diperoleh senyawa antioksidan baru yang aman dari sumber bahan alam.

Pezzuto and Park [5] dan Everet et al. [6] mengungkapkan bahwa kerusakan oksidatif dapat dihambat oleh senyawa penangkap radikal bebas dan penyumbang elektron seperti senyawa fenol. Senyawa fenol mampu menghambat radikal bebas dengan mekanisme sumbangan hidrogen dan stabilisasi resonansi [7].

Penelitian pendahuluan terhadap daun dewandaru (Eugenia uniflora Linn.) menunjukkan adanya aktivitas antiradikal DPPH pada ekstrak etanol, ekstrak etil asetat dan ekstrak kloroform. Hasilnya menunjukkan bahwa aktivitas antiradikal dari ekstrak etanol dan atil asetat tersebut hampir setara dengan vitamin E, suatu antioksidan yang poten [8]. Tumbuhan dewandaru mengandung senyawa-senyawa fenolik antara lain flavonoid yang kemungkinan bertanggung jawab terhadap aktivitas antiradikal tumbuhan dewandaru $[9,10]$.

Flavonoid memiliki kemampuan menghambat peroksidasi lipid, membentuk kelat dengan logam dan mengurangi proses lain yang melibatkan ROS (reactive oxygen species). Kekuatan flavonoid sebagai antioksidan tergantung struktur molekulnya. Posisi hidroksil dan substitusi lainnya pada struktur sangat penting untuk aktivitas pembersihan (scavenging) radikal bebas [11]. Penelitian ini dilakukan untuk menentukan fraksi aktif dari ekstrak etanol dan ekstrak etil asetat daun dewandaru sebagai antiradikal dikaitkan dengan kandungan senyawa fenolik dan kandungan flavonoidnya.

\section{Bahan dan Metode}

Bahan yang digunakan dalam penelitian ini adalah: daun dewandaru (Eugenia uniflora L) yang diperoleh dari Balai Pembudidayaan Tanaman Obat Tawangmangu.

Ekstrak daun dewandaru diperoleh dengan cara maserasi bertingkat serbuk daun dewandaru menggunakan pelarut berturutturut kloroform, etil asetat dan etanol berderajat teknis. Selanjutnya dilakukan fraksinasi hanya terhadap ekstrak etil asetat dan etanol, karena dalam penelitian sebelumnya [8] ekstrak kloroform tidak menunjukkan aktivitas antiradikal yang potensial.

Fraksinasi dilakukan dengan metode kromatografi kolom gravitasi menggunakan fase diam silica gel dan 11 macam fase gerak, masing-masing sebanyak $200 \mathrm{ml}$, yang terdiri dari kloroform, etil asetat, etanol, dan air dengan perbandingan volume yang bervariasi secara gradien kepolaran (Tabel 1).

\begin{tabular}{ccccc} 
Tabel 1. Perbandingan Volume Fase Gerak yang Digunakan pada Fraksinasi Ekstrak Etil Asetat dan Ekstrak Etanol Daun Dewandaru \\
$\begin{array}{ccc}\text { Fase Gerak } \\
\text { ke- }\end{array}$ & Kloroform $(\%)$ & Etil Asetat $(\%)$ & Air $(\%)$ \\
\hline 1 & 100 & 0 & 0 & 0 \\
2 & 75 & 25 & 0 & 0 \\
3 & 50 & 50 & 0 & 0 \\
4 & 25 & 75 & 0 & 0 \\
5 & 0 & 100 & 0 & 0 \\
6 & 0 & 75 & 25 & 0 \\
7 & 0 & 50 & 50 & 0 \\
8 & 0 & 25 & 75 & 0 \\
9 & 0 & 0 & 100 & 25 \\
10 & 0 & 0 & 75 & 50 \\
11 & 0 & 0 & 50 & 0 \\
\hline
\end{tabular}

Aktivitas antiradikal ditentukan dengan metode DPPH (2,2-diphenyl-1-picrylhidrazyl). Sejumlah larutan sampel ekstrak, fraksi, atau pun vitamin E masing-masing ditambah dengan 1,0 ml DPPH 0,4 mM dan etanol ad 5,0 ml. Campuran tersebut divorteks selama 30 detik dan diinkubasi selama 45 menit. Absorbansi sampel diukur terhadap blangko yang terdiri dari sejumlah larutan stok dalam etanol pada $\lambda_{\text {maks }} 516 \mathrm{~nm}$. Aktivitas antiradikal dilihat dari adanya penurunan absorbansi dibandingkan dengan kontrol yang terdiri dari $1,0 \mathrm{ml}$ DPPH $0,4 \mathrm{mM}$ dalam etanol. Persen (\%) penangkap radikal dihitung menggunakan persamaan berikut:

\section{$\frac{\text { (Absorbansi kontrol-Absorbansi sampel) }}{\text { Absorbansi kontrol }} \times 100 \%$}

Penentuan aktivitas antiradikal dilakukan melalui perhitungan nilai $\mathrm{IC}_{50}$, yaitu nilai yang menggambarkan besarnya konsentrasi sampel yang dapat menangkap radikal bebas sebesar $50 \%$. $\mathrm{IC}_{5 \mathrm{O}}$ diperoleh dari persamaan regresi antara konsentrasi sampel (X) dengan rerata aktivitas penangkap radikal (Y) dari seri replikasi pengukuran. Nilai EC $_{50}$ (efficiency concentration) diperoleh berdasarkan data $\mathrm{IC}_{50}$ melalui persamaan berikut:

$$
\frac{\mathrm{IC}_{50}(\mathrm{mg} / \mathrm{mL})}{\text { Konsentrasi DPPH }(\mathrm{mg} / \mathrm{mL})}
$$

Nilai $\mathrm{EC}_{50}$ dinyatakan dalam mg sampel tiap mg DPPH. 
Selanjutnya nilai antiradical power (ARP) [12] dengan satuan mg DPPH/mg sampel, dihitung berdasarkan nilai EC 50 yang didapatkan melalui persamaan berikut:

$\frac{100}{E C_{50}}$

Kandungan fenol total dalam ekstrak dan fraksi ditentukan dengan metode Folin-Ciocalteu sesuai yang dilakukan oleh Lee $e t$ al. [13] dengan beberapa modifikasi menggunakan asam galat sebagai standar. Kandungan fenol total dinyatakan sebagai ekivalensi milligram asam galat dalam tiap gram ekstrak (GAE).

Kandungan flavonoid total dalam ekstrak dan fraksi ditentukan dengan metode kolorimetri $\mathrm{AlCl}_{3}$ sesuai yang dilakukan oleh Zhishen et al. (1999) cit Karadeniz et al. [14] menggunakan rutin sebagai standar. Kandungan flavonoid total dinyatakan sebagai ekivalensi miligram rutin dalam tiap gram ekstrak (RE).

\section{Hasil dan Pembahasan}

Fraksinasi terhadap ekstrak etanol dan ekstrak etil asetat dilakukan secara bertingkat berdasar gradien kepolaran untuk memisahkan senyawa-senyawa yang terdapat dalam ekstrak etil asetat dan ekstrak etanol sesuai dengan kemampuannya untuk larut dalam seri eluen yang digunakan. Hasil dari fraksinasi ekstrak etil asetat diperoleh 20 efluen, kemudian dikelompokkan berdasarkan pada kesamaan profil KLT-nya sehingga didapatkan sembilan fraksi. Sementara dari hasil fraksinasi ekstrak etanol diperoleh 15 efluen yang dikelompokkan menjadi delapan fraksi berdasarkan kesamaan profil KLT-nya. Hasil fraksinasi tercantum pada Tabel 2 .

Uji aktivitas antiradikal DPPH oleh sampel uji berdasarkan prinsip penurunan intensitas warna ungu DPPH yang sebanding dengan penurunan konsentrasi DPPH. Senyawa uji sebagai antiradikal akan memberikan hidrogen kepada DPPH membentuk DPPH-H tereduksi yang berwarna kuning [15]. Senyawa penangkap radikal yang telah menyumbangkan $H$ radikal berubah menjadi radikal baru. Antiradikal yang bermanfaat adalah senyawa yang setelah bereaksi dengan radikal bebas menghasilkan radikal baru yang stabil.

\begin{tabular}{cccccc}
\multicolumn{5}{c}{ Tabel 2. Hasil Fraksinasi Ekstrak Etil Asetat dan Ekstrak Etanol Daun Dewandaru } \\
\hline $\begin{array}{c}\text { Fraksi dari ekstrak } \\
\text { etanol }\end{array}$ & Efluen & $\begin{array}{c}\text { Berat fraksi dari } \\
\text { ekstrak etano } \\
\text { kering }(\mathrm{g})\end{array}$ & $\begin{array}{c}\text { Fraksi ekstrak etil } \\
\text { asetat }\end{array}$ & Efluen & $\begin{array}{c}\text { Berat fraksi dari } \\
\text { ekstrak etil asetat } \\
\text { kering }(\mathrm{g})\end{array}$ \\
\hline EtOH I & 1 & 0,0664 & EtOAc I & $1+2$ & 28,434 \\
EtOH II & 2 & 0,0310 & EtOAc II & 3 & 0,0989 \\
EtOH III & $3+4$ & 0,0409 & EtOAc III & $4+5+6$ & 20,253 \\
EtOH IV & $5+6$ & 0,0659 & EtOAc IV & $7+8+9+10$ & 0,7438 \\
EtOH V & $7+8$ & 0,1989 & EtOAc V & $11+12$ & 0,3932 \\
EtOH VI & 9 & 13602 & EtOAc VI & $13+14+15$ & 0,0578 \\
EtOH VII & 10 & 0,8047 & EtOAc VII & $16+17$ & 0,0393 \\
EtOH VIII & $11+12+13+14$ & 0,4340 & EtOAc VIII & $18+19$ & 0,0166 \\
& +15 & & EOtAc IX & 20 & 0,0217 \\
\hline
\end{tabular}

Aktivitas penangkap radikal dinyatakan dalam $\mathrm{IC}_{50}, \mathrm{EC}_{50}$ dan ARP. Semakin besar nilai ARP menunjukkan kemampuan antiradikal senyawa tersebut semakin besar. Hasil penelitian menunjukkan bahwa aktivitas antiradikal berbagai fraksi dari ekstrak etil asetat dan ekstrak etanol daun dewandaru bervariasi (Tabel 3). Fraksi dari ekstrak etil asetat yang menunjukkan aktivitas antiradikal lebih kuat dibandingkan dengan ekstrak etil asetat yaitu fraksi IV (ARP=1219,51 mg DPPH/mg sampel) dan fraksi V (ARP= 1666,67 mg DPPH/mg sampel). Pada ekstrak etanol, fraksi VI (ARP= 3496,5 mg DPPH/mg sampel) memiliki aktivitas antiradikal lebih kuat dibanding ekstrak etanol. Hal ini menunjukkan bahwa senyawa-senyawa yang bertanggungjawab terhadap aktivitas antiradikal pada ekstrak etil asetat sebagian besar terdapat dalam fraksi IV dan V, sedangkan senyawasenyawa yang bertanggungjawab terhadap aktivitas antiradikal pada ekstrak etanol sebagian besar terdapat dalam fraksi VI.

Secara umum, jika dibandingkan dengan vitamin E, fraksi polar memiliki potensi antiradikal yang lebih kuat daripada vitamin E, yaitu mulai dari fraksi IV ekstrak etanol sampai dengan fraksi VIII ekstrak etanol (Tabel 3). Oleh karena itu, fraksi polar dari ektrak etanol sangat potensial untuk dikembangkan menjadi antiradikal alami dengan aktivitas yang tinggi. Namun karena beragamnya kandungan senyawa yang dimiliki kedua fraksi tersebut, menyebabkan senyawa yang berperan terhadap aktivitas antiradikal belum dapat ditentukan.

Prinsip penentuan kandungan fenol dengan reagen Folin Ciocalteu adalah terbentuknya senyawa molibdenum yang berwarna biru dari hasil reduksi fosfomolibdat fosfotungstat oleh senyawa fenolik. Intensitas warna biru yang terbentuk dapat diukur 
secara spektrofotometri dan dinyatakan dalam Gallic Acid Equivalent yaitu jumlah kesetaraan miligram asam galat dalam 1 gram bahan. Semua senyawa fenol termasuk fenol sederhana dapat bereaksi dengan reagen Folin Ciocalteu.

\begin{tabular}{|c|c|c|c|}
\hline Sampel & $\begin{array}{c}\mathrm{IC}_{50} \\
(\mu \mathrm{g} / \mathrm{mL})\end{array}$ & $\begin{array}{c}\mathrm{EC}_{50} \\
(\mathrm{mg} / \mathrm{mg} \mathrm{DPPH})\end{array}$ & $\begin{array}{c}\text { ARP } \\
\text { (mg DPPH/mg sampel) }\end{array}$ \\
\hline Ekstrak Etil Asetat & 29,08 & 0,184 & 543,5 \\
\hline EtOAc I & 176,40 & 1,116 & 89,61 \\
\hline EtOAc II & 309,48 & 1,959 & 51,05 \\
\hline EtOAc III & 105,49 & 0,668 & 149,70 \\
\hline EtOAc IV & 13,02 & 0,082 & 1219,51 \\
\hline EtOAc V & 9,43 & 0,060 & 1666,67 \\
\hline EtOAc VI & 129,02 & 0,817 & 122,40 \\
\hline EtOAc VII & 30,99 & 0,196 & 510,20 \\
\hline EtOAc VIII & 63,31 & 0,401 & 249,38 \\
\hline EtOAc IX & 306,77 & 1,942 & 51,49 \\
\hline Ektrak Etanol & 4,63 & 0,029 & 3460,21 \\
\hline EtOH I & 1774,60 & 11,090 & 9,02 \\
\hline EtOH II & 630,26 & 3,940 & 25,38 \\
\hline EtOH III & 191,88 & 1,200 & 83,33 \\
\hline EtOH IV & 6,80 & 0,043 & 2325,6 \\
\hline EtOH V & 5,00 & 0,031 & 3194,9 \\
\hline EtOH VI & 4,57 & 0,029 & 3496,5 \\
\hline EtOH VII & 7,81 & 0,049 & 2049,18 \\
\hline EtOH VIII & 8,99 & 0,056 & 1779,36 \\
\hline Vit E & 8,90 & 0,056 & 1776,20 \\
\hline
\end{tabular}

Hasil penelitian (Tabel 4) menunjukkan fraksi VI dari ekstrak etanol memiliki kadar fenol total paling tinggi $(373,11 \mathrm{mg} / \mathrm{g}$ sampel) dan aktivitas antiradikal paling kuat (ARP=3496,5 mg DPPH/mg sampel), sedangkan fraksi I etanol memiliki kadar fenol total paling rendah $(20,28 \mathrm{mg} / \mathrm{g}$ sampel) dan aktivitas antiradikal paling lemah (ARP=9,02 mg DPPH/mg sampel). Hubungan kadar fenol total dengan aktivitas antiradikal berbagai fraksi ekstrak etil asetat dan ekstrak etanol menunjukkan korelasi positif dengan korelasi sebesar 0,55. Hal ini menunjukkan bahwa lebih dari 50\% aktivitas antiradikal berbagai fraksi tersebut disumbangkan oleh senyawa fenol, sedangkan sisanya disumbangkan oleh senyawa lain. Menurut Javanmardi et al. [16], aktivitas antiradikal dari ekstrak tumbuhan tidak hanya terbatas oleh senyawa fenol tetapi juga disumbangkan oleh senyawasenyawa seperti minyak menguap, karotenoid dan vitamin C.

Kebanyakan senyawa fenol alam telah diketahui strukturnya dan flavonoid merupakan golongan terbesar [17]. Menurut Midlleton et al. [18], flavonoid mempunyai aktivitas sebagai antioksidan, sehingga diperkirakan flavonoid yang berperan dalam aktivitas antiradikal bebas. Oleh karena itu perlu penetapan kadar flavonoid total dari masing-masing fraksi.

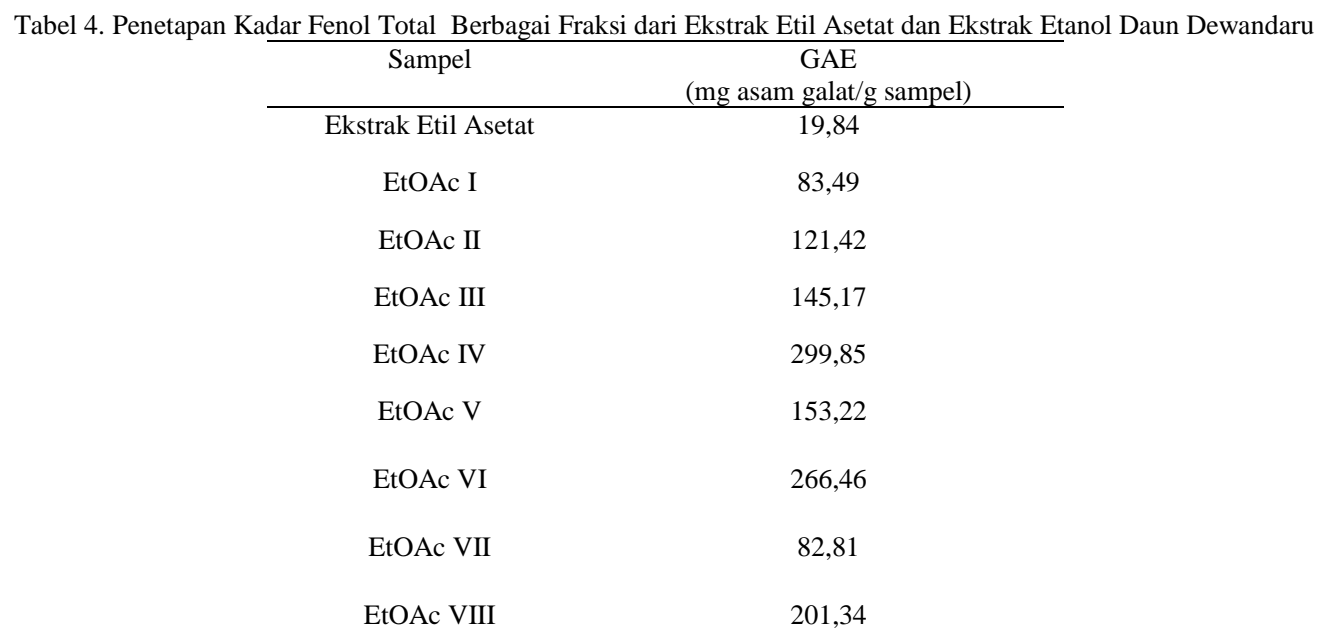




\begin{tabular}{cc}
\hline EtOAc IX & 41,78 \\
Ekstrak Etanol & 315,63 \\
EtOH I & 20,28 \\
EtOH II & - \\
EtOH III & - \\
EtOH IV & 154,37 \\
EtOH V & 195,46 \\
EtOH VI & $\mathbf{3 7 3 , 1 1}$ \\
EtOH VII & 156,38 \\
EtOH VIII & 143,45 \\
\hline
\end{tabular}

Kadar flavonoid ditetapkan dengan menggunakan metode kolorimetri alumunium klorida dengan pengukuran absorbansi secara spektrofotometri. Alumunium klorida akan membentuk kompleks dengan gugus hidroksi keton atau orto hidroksi sehingga memperpanjang panjang gelombang ke arah visibel (efek batokromik) [17]. Kandungan flavonoid dalam ekstrak dan fraksi dinyatakan dalam Rutin Equivalent yaitu jumlah kesetaraan milligram rutin dalam 1 gram bahan yang ditetapkan.

Hasil penetapan kadar flavonoid total menunjukkan bahwa fraksi VIII ekstrak etanol memiliki kandungan flavonoid paling tinggi (269 mg/g sampel), sedangkan fraksi I ekstrak etanol memiliki kandungan flavonoid paling rendah (57,91 mg/g sampel) (Tabel 5). Hubungan antara kadar flavonoid total berbagai fraksi ekstrak etil asetat dan ekstrak etanol dengan aktivitas penangkap radikalnya berkorelasi positif sebesar 0,45 .

\begin{tabular}{cc} 
Tabel 5. Penetapan Kadar Flavonoid Total Berbagai Fraksi dari Ekstrak Etil Asetat dan Ekstrak Etanol Daun Dewandaru \\
\cline { 2 - 3 } Sampel & $\begin{array}{c}\text { RE } \\
(\mathrm{mg} / \mathrm{g} \text { sampel })\end{array}$ \\
\hline Ekstrak Etil Asetat & 279,31 \\
EtOAc I & 358,59 \\
EtOAc II & 224,65 \\
EtOAc III & 151,42 \\
EtOAc IV & 173,30 \\
EtOAc V & 200,23 \\
EtOAc VI & 92,74 \\
EtOAc VII & 136,54 \\
EtOAc VIII & 269,34 \\
EtOAc IX & 88,29 \\
Ektrak Etanol & 189,82 \\
EtOH I & 57,91 \\
EtOH II & 68,41 \\
EtOH III & 68,41 \\
EtOH IV & 253,784 \\
EtOH V & 104,234 \\
EtOH VI & 206,41 \\
EtOH VII & 179,91 \\
EtOH VIII & 462,62 \\
\hline
\end{tabular}

Hasil penelitian secara keseluruhan menunjukkan kandungan flavonoid tinggi belum tentu menyebabkan aktivitas antiradikal yang kuat (Tabel 5). Hal ini menunjukkan bahwa aktivitas antiradikal belum tentu disumbangkan oleh besarnya kandungan fenol dan flavonoid total, namun harus didukung pula oleh struktur fenol dan flavonoid tersebut. Penelitian yang dilakukan Amić et al. [19] dan Farkas et al. [20] menyatakan bahwa aktivitas antiradikal flavonoid tergantung pada struktur molekul dan pola substitusi gugus hidroksinya serta pada ketersediaan hidrogen fenol dan kemungkinan hasil dari stabilisasi radikal fenoksil 
melalui ikatan hidrogen atau delokalisasi elektron. Semakin banyak substitusi gugus hidroksi pada flavonoid maka aktivitas antiradikalnya semakin besar. Silva et al. [21] dan Amić et al. [19] menyatakan juga bahwa adanya gugus orto-katekol (3',4'$\mathrm{OH})$ pada cincin B flavonoid merupakan faktor penentu kapasitas antioksidan yang tinggi.

\section{Kesimpulan}

Berdasarkan hasil diatas, dapat disimpulkan bahwa fraksi VI dari ekstrak etanol memiliki aktivitas antiradikal yang paling tinggi dengan nilai ARP (antiradical power) 3496,5 mg DPPH/mg sampel. Fraksi polar dari ekstrak etanol (fraksi IV, V, VI, VII dan VIII) daun dewandaru memiliki aktivitas antiradikal yang lebih tinggi dibandingkan vitamin E. Kandungan fenol dan flavonoid total berbagai fraksi dari ekstrak etil asetat dan ekstrak etanol daun dewandaru memiliki korelasi yang rendah dengan aktivitas antiradikalnya.

\section{Daftar Pustaka}

[1] Ozsoy, N., Can, A., Yanardag, R., Akev, N., 2008, Antioxidant Activity of Smilax excels Leaf Extract, Food Chem, Vol 1, No. 10, 571-583.

[2] Sasikumar, JM., Jinu, U., Sharma, R., 2009, Antioxidant Activity and HPLC Analysis of Pandanas odoratissimus L. Root, Euro J Biology Sci., Vol. 1, No. 2, 17-22

[3] Han, S.S., Lo, S.C., Choi, Y.W., Kim, J.H., and Baek, S.H., 2004, Antioxidant Activity of Crude Extract and Pure Compounds of Acer ginnala Max., Bull. Korean Chem. Soc., Vol. 25, No. 3389.

[4] Kikuzaki, H., Hisamoto, M., Hirose, K., Akiyama, K., and Taniguchi, H., 2002, Antioxidant Properties of Ferulic Acid and Its Related Compounds, J. Agriculture Food Chem., 50, 2161-2168.

[5] Pezzuto,J. and Park, E.J.,2002, Autooxidation and Antioxidants in Swarbrick, J., Boylan, J.C., 2002, Encyclopedia of Pharmaceutical Technology, Vol I, $2^{\text {nd }}$ edition, 97-100, 109-111, Marcell-Dekker, USA.

[6] Everett, S.A., Dennis, M.F., Patel, K.B., Maddix, S., Kundu, S.C., and Willson, R., 1996, Scavenging of Nitrogen Dioxide, Thyl and Sulfonyl Free Radical by The Nutritional Antioxidant, J. Bio. Chem., Vol. 271; No. 8, Issue February 23, 3988-3994.

[7] Fessenden, R.J. and Fessenden, J.S., 1986, Kimia Organik, Jilid I, Edisi III, 223-226, 238-240, Alih Bahasa: A.H. Pudjaatmaka, Erlangga, Jakarta.

[8] Utami, W., Da'i, M., dan Sofiana, Y.R., 2005, Uji Aktifitas Penangkap Radikal dengan Metode DPPH serta Penetapan Kandungan Fenol dan Flavonoid dalam Ekstrak Etanol, Etil Asetat dan Kloroform Daun Dewandaru (Eugenia uniflora L.), Pharmacon, 6(1), 5-9.

[9] Einbond, L., Reynertson, K.A., Luo, X. D., Basile, M.J., and Kennely, E.J., 2004, Anthocyanin Antioxidants from Edible Fruits, Food Chem., 84, 23-28.

[10] Hutapea J.R., Soeharso, Sutjipto, Djumidi, Sugiarso S., Widiyastuti Y., dan Sihotang, 1991, Inventaris Tanaman Obat Indonesia, edisi III, 45-46, Departemen Kesehatan Republik Indonesia, Jakarta.

[11] Heim, K.E., Tagliaferro, A.R., and Bobilya, D.J., 2002, Flavonoid: antioxidants: chemistry, metabolism and structure-activity relationships, J. Nutritional Biochem.,13 (10), 572-584.

[12] Prakash, D., Upadhyay, G., Singh, B. N., Dhakarey, R., Kumar, S., and Singh, K.K., 2007, Free-radical Scavenging Activities of Himalayan Rhododendrons, Current Science, Vol. 92, No. 4, 25.

[13] Lee, K.W., Kim, Y. J., Lee, H.J., Lee, C.Y., 2003, Cocoa Has More Phenolic Phytochemical and a Higher Antioxidant Capacity than Teas and Redwine, J. Agriculture Food Chem., 51(25), 7292-7295.

[14] Karadeniz, F., Burdurlu, H.S., Koca, N., and Soyer, Y., 2005, Antioxidant Activity of Selected Fruits and Vegetables Grown in Turkey, Turk J. Agriculture and Forestry, 29 (2005), 297-303.

[15] Huang, D., Ou, B., and Prior, R.L., 2004, Reviews The Chemistry Behind Antioxidant Capacity Assays, J. Agric. Food Chem., 53, $1841-1856$.

[16] Javanmardi, J., Stushnoff, C., Lockeb, E., and Vivancab, J.M., 2003, Antioxidant Activity and Total Fenolic Content of Iranian Ocimum accessions, J.Food Chem., 83: 547-550.

[17] Harborne, J.B., 1987, Metode Fitokimia : Penuntun Cara Modern Menganalisis Tumbuhan, diterjemahkan oleh Kosasih Padmawinata, Terbitan ke-2, ITB, Bandung.

[18] Midleton, E., Kandaswami, C., and Theoharis, L., 2000, The Effect of Plant Flavonoids on Mammalian Cells: Implication For Inflammation, Heart Disease \& Cancer, Pharmacological Reviews, Vol. 52, No.4, 711-722.

[19] Amić, D., Davidović- Amić, D., Beslo, D, and Trinajstić, 2003, Structure-Radical Scavenging Activity Relationships of Flavonoids, Croatia Chemica Acta, 76 (1), 55-61.

[20] Farkas, O., Judit, J., and Héberger, K., 2004, Quantitative Structure-Antioxidant Activity Relationships of Flavonoid Compounds, Molecules, 9, 10791088.

[21] Silva, M.M., Santos, M.R., Caroço,G., Rocha, R., Justino, G., and Mira, L., 2002, Structure-antioxidant Activity Relationships of Flavonoids: A ReExamination, Free Radical Research, 36 (11), 1219-1227. 